\title{
INTRODUCTION: \\ AESTHETICS OF FINANCE
}

Money is not merely a major driver of human behaviour, it is also an expression of given states of affairs and their future potential. French historian Marc Bloch noted that monetary phenomena are like "a seismograph that not only registers earth tremors, but sometimes brings them about" 1 and contemporary financial sociologist Martijn Konings described similar dynamics for current value formations: "Value is not given before it is signified: the signification of value is performative rather than passively representational."2

The aesthetics of monetary phenomena, of the signification of value, of financial transactions, are, thus, anything but passive. They are the very core of economic agency. In her magisterial historical study of the aesthetics of capital, Susan Buck-Morss noted that "Because the economy is not found as an empirical object among other worldly things, in order for it to be "seen" by the human perceptual apparatus it has to undergo a process, crucial for science, of representational mapping."3

Such representational mappings present a problem within a wide variety of aesthetic forms: within literature, the contemporary economy poses a narrative problem. In Don DeLillo's Cosmopolis (2003), "[m]oney has lost its narrative quality the way painting did once upon a time,"4 just as in Paul Murray's The Mark and the Void (2015) the problem of narrative representation is that "nothing happens. There's no story there. [...] I know there's a big story behind it, I know the bank is expanding and growing and so on, but I can't see any of that." ${ }^{5}$ Within art, a large number of works appear as "a representational and often investigative device that strives to communicate the experiential and affective dimensions of commodification and alienation" 6 concurrent with the financialisation of daily life. In recent years, the work of artists such as Melanie Gilligan, Goldin + Senneby, Gerald Nestler, Beater Geissler \& Oliver Sann, and Zachary Formwalt, participated in these artistic investigations along with the works and curatorial practices in several exhibitions, e.g. It's the Political Economy, Stupid (Austrian Cultural Forum New York, 2012) and Show Me the Money: The Image of Finance, 1700 to the Present (Northern Gallery for Contemporary Art, 2014).

Although the economic circulation and social operations of money have perennially preoccupied aesthetic practices, 
economic abstraction has increased in a way that further aggravates the problem of its representation. Since the beginning of the 1970s, financial institutions have evolved to become some of the most powerful nodes of social and political operations and financialized modes of perceiving and acting are pervasive in all aspects of life. Consequently, the interest in understanding the logic of finance and the practices of financialization has spread far beyond the narrow circles of economists and bankers. The experience of the financial crisis of 2007-8, in particular, has given rise to a substantial general engagement with finance, both in critical finance studies-drawing on insights from sociology, anthropology, and history, disciplines that have not traditionally fallen within the purview of modern economics-and within the aesthetic forms of artworks, literature, and cinema.

These approaches have furthered our understanding of how financial capitalism mediates power relations and social distributions, how it operates through specific modes of interaction and agency, and how it is inscribed in historical modes and means of production and the social organizational forms they entail. The perceived relative importance of critical finance studies and the aesthetic engagements with financialization has not been even, however. As pointed out by Leigh Claire La Berge: "[O]ur hierarchies of disciplinary knowledge mean that cross-disciplinary traffic moves largely down a one-way street; humanities reads social science but social science does not read humanities.”7

Perhaps it is due time that such one-sidedness is overcome. In addition to-and in dialogue with-the emerging critical approaches to financialization, we propose the present issue of The Nordic Journal of Aesthetics as a contribution to a specifically aesthetic mode of the critical study of finance. Such an aesthetics of finance refers to cultural artefacts that engage with the world of finance; but it also refers to a historically specific way of perceiving, feeling, imagining, anticipating, and acting upon our given reality as it is increasingly produced and determined by the logic of finance.

Informed by both economic history and a wide variety of aesthetic disciplines, the present issue probes how cultural artefacts provide representational maps through which our daily interactions with money as well as the arcane abstractions of high finance find an expression that one can see, feel, judge, and discuss. We thus work towards understanding of what could be called, with Sianne Ngai, the aesthetic categories of financial capitalism, i.e. 
the judgments we utter and the forms we perceive, the way we speak and the way we see; as well as towards understanding of how artistic production engages in the creation of forms that are able to grasp and exhibit these categories and their operations in our contemporary societies.

The articles in this issue take stock of the current, inherently global state of financialization, and provide some key-analytical, historical, conceptual and political_coordinates for engaging in an analysis and a critique of it. The issue opens with "The Right Tools for the Job: The Right Job for Our Tools” by Mary Poovey, an article based on a keynote she gave at the 2019 Norlit (The Nordic Association for Literary Research) conference "Money and Literature: Wealth, Finance, Aesthetics" at the University of Copenhagen, a conference from which the idea of this special issue arose and which was co-organized by the research project Finance Fiction-Financialization and Culture in the Early 21st Century to which the guest editors of the current issue belong. In the article, Poovey confronts the methodological question of how researchers from the departments of literary and cultural studies can use their tools to investigate not just economic themes in literary works but also read economic texts-theory books, money guides, newspaper articles-from a literary point of view. And, importantly, whether that might lead to a proper crossdisciplinary dialogue between, say, economists and literary scholars. It is, as she argues, as important as it is hard.

Solveig Daugaard's article “'Anybody living a private life is a believer in money.' Gertrude Stein, the Great Depression, and the abstraction of money" examines the historical period of the 1930s and the Great Depression through a number of Gertrude Stein's writings on money. In her reading of Stein's political alternations between conservativism and radicalism in her intense preoccupation with the increasing abstraction of the economy, Daugaard argues for a serious consideration of the relation between modernism and the marketplace, between literature and money, and between the aesthetic and the economic sphere. Dominique Routhier, in his piece "Full Automation in its Infancy: the Situationist Avant-garde book Fin de Copenhague," focuses less on the abstraction of the economy than on the automation of work. Taking the Situationist Fin de Copenhague, a joint artistic enterprise undertaken by Asger Jorn and Guy Debord in May 1957, as his historical and archival point of departure, Routhier places the publication "in a longer trajectory of avant-garde 
'political aesthetics' to highlight the ways in which the book selfconsciously thematizes capitalist production as inseparable from artistic production," and, also, the ways in which a restoration of the book to its original context can be used to illuminate the inherent, yet intricate entanglement of work and art and the nascent program of "full automation."

Following the important historical work of these two articles, the next two center around the classical Marxist concepts of commodities and class, respectively, while also departing somewhat from the orthodox meaning of these terms. Kristina Malmio, in "Marx et Co Revisited. Representations of the Economy in Ralf Andtbacka's Wunderkammer (2008)," reads Finnish-Swedish author Ralf Andtbacka's fifth collection of poetry as an allegorical representation of the current state of capitalism, a cabinet of commodified curiosities, as it were. Malmio thus argues that the book provides a cognitive mapping, playing with various forms of value: surplus value, collector value, use value, exchange value, artistic value, etc. But by doing so, Andtbacka's book, in Malmio's reading, not only adheres to theories of capital, but offers a "highly nuanced re-evaluation of capitalism" and a glimpse of a "post-capitalist model." In "Revolution or Diversity? Aesthetic and Political Manifestations of Class in Three Swedish Radical Picture Books from the 2000s and 2010s" Kristina Hermansson hones in on the question of class in Swedish children's picture books from the 2000s and 2010s. Paying close attention to these books' verbal and visual elements, while also comparing them to the politically radical children's books of the 1970s, Hermansson is able to pinpoint how the representations of class operate in three specific examples and to explore how the political and the aesthetic merge in the very act of representing.

Naturally, the financial crisis of 2007-8 also figures prominently in this issue. As the title of the article intimates, Vera Knútsdóttir, in "Spectral Memories-Aesthetic Responses to the Financial Crash in Iceland 2008," analyzes fiction and visual art that confronts the crisis in Iceland. Concentrating on I Remember You, a crash-horror story by crime writer Yrsa Sigurðardóttir, and a series of photo-realist drawings of half-built houses by visual artist Guðjón Ketilsson, Knútsdóttir details how these works operate-again, verbally as well as visually — within the register of the horror genre, expressing the uncanny and spectral dimensions of the crisis, not least with regards to the motif of haunted houses and the 'impossibility' of mourning. If spectrality is a keyword 
in Knútsdóttir's article, materiality is at the forefront of Emma Sofie Brogaard Jespersen's "Sensibility and Semio-capitalism-a Bodily/Material Experience of Crisis in Ursula Andkjær Olsen's The Crisis Notebooks.” Jespersen draws upon the work of Franco 'Bifo' Berardi and employs the concept of sensibility to read Danish author Ursula Andkjær Olsen's complex and polyphonous novel The Crisis Notebooks as a meditation on the relation between body and crisis. Adding a much-needed focus on materiality to the field of finance studies, critical or otherwise, the article, then, explores the novel's affective, aesthetic, and political strategies to deal with the bodily experience of the crisis.

Initiating a shift in time as well as geography, Nick Huber's "Money as Frame” analyzes our contemporary moment, 2020, COVID-19 and the tragic case of George Floyd who was arrested and killed because of the supposed use of a counterfeit twentydollar bill. The article studies the notion of essential work, unemployment and, in particular, the role of money during the pandemic. Responding to the text "Money as Art: The Form, the Material, and Capital" by the Marxist economist Costas Lapavitsas, Huber problematizes the posited identity of money and art, and advances the argument that the ongoing crisis, still unfolding at the time of this writing, raises pertinent questions of race and class that can only be dealt with from a Marxist perspective, but one that recognizes that the "aesthetic function of money in the capitalist mode of production is inseparable from its total social function."

Last but not least, Joseph Vogl's "The Financial Regime” is a precise account of how the financial regime has become a power in and of itself and how this has led to a specific geo-economical order. The latter part of the essay consists of five theses, the central part of which revolves around what Vogl calls a new financial sovereignty, ending with the original and useful definition that sovereign is he who can transform his risks into other's dangers and position himself as the creditor of last resort. This rounds off the collection of articles which we, as editors, hope can serve as a basis for future explorations into the aesthetics of money and finance as well as contribute to further cross-disciplinary conversations.

Torsten Andreasen, Mikkel Krause Frantzen, and Frederik Tygstrup, guest editors 
1 Marc Bloch, "The Problem of Gold in the Middle Agnes," in Land and Work in Medieval Europe (London: Routledge, 2015), 186.

2 Martijn Konings, Capital and Time: For a New Critique of Neoliberal Reason (Stanford, Ca.: Stanford University Press, 2018), 11.

3 Susan Buck-Morss, "Envisioning Capital: Political Economy on Display," Critical Inquiry, Vol. 21, No. 2 (Winter, 1995): 440.
4 Don DeLillo, Cosmopolis (New York: Scribner, 2003), 77.

5 Paul Murray, The Mark and the Void (London: Penguin, 2015).

6 Victoria Ivanova \& Gerald Nestler, "Art, Markets, and Finance," in The Routledge Handbook of Critical Finance Studies (New York: Routledge, 2020), 385.

7 Leigh Claire La Berge, "Money is time: On the possibility of critique after neoliberalism," Finance and Society 2(4) (2018): 203. 